\title{
WAARDENBURG SYNDROME TYPE II: A CASE REPORT
}

\author{
Santosh Kumar Singh ${ }^{1}$, Sunil Kumar Gupta ${ }^{2}$, Anand Agarwal ${ }^{3}$
}

\section{HOW TO CITE THIS ARTICLE:}

Santosh Kumar Singh, Sunil Kumar Gupta, Anand Agarwal. "Waardenburg Syndrome Type II: A Case Report". Journal of Evolution of Medical and Dental Sciences 2014; Vol. 3, Issue 55, October 23; Page: 12687-12689, DOI: $10.14260 /$ jemds/2014/3681

ABSTRACT: Waardenburg syndrome is a rare syndrome, characterized by lateral displacement of the medial canthi combined with dystopia of the lacrimal punctum and blepharophimosis, prominent broad nasal root, hypertrichosis of the medial part of the eyebrows, white forelock, heterochromia iridis, and deaf mutism. A four months old girl with waardenburg syndrome type II, who had the characterstic features of the syndrome, is reported.

KEYWORDS: Waardenburg syndrome, Heterochromia iridis, Deaf mutism.

INTRODUCTION: Waardenburg syndrome is a bunch of hereditary conditions characterized by lateral displacement of the medial canthi combined with dystopia of lacrimal puncta and blepharophimosis, prominent broad nasal root, hypertrichosies of medial part of the eyebrows, white forelock, heterochromia iridis and deaf mutism.

Special facies or facial asymmetry, skin manifestations, fundus pigmentry abnormalities, facial palsy, musculoskeletal abnormalities (aplasia of the first two ribs, lack of differentiation of the small carpal bones, cystic formation of the sacrum, abnormalities of arms like amyoplasia and stiffness of the joints, and cutaneous syndactyly), microcephaly, mental retardation and hirschsprung disease have also been revealed in the literature.

Internationally the incidence of the syndrome with or without deafness is approximately 1 case per 42, 000 persons. The syndrome is evident in $0.9-2.8 \%$ of persons with deafmutism. All races are affected and there is no sex differenciation. ${ }^{1}$ In this light a four months old female infant with warrdenberg syndrome type II who fulfilled the diagnostic criteria of the syndrome, is being reported.

CASE REPORT: A 4 months old female infant presented with complete heterochromia (right eye: complete blue iris) with normal facies. She was second child, born by normal vaginal delivery in a hospital. She was a product of a consanguineous marriage. No insult had been noticed during antenatal, perinatal or in postnatal period. There was no family history of same type of ailment in the first or second degree relatives.

On examination, her weight was $4.2 \mathrm{~kg}$, length was $51 \mathrm{~cm}$ and head circumference was $39 \mathrm{~cm}$. She had complete right sided blue iris (complete heterochromia iridum), normal facies with normal eye brows and eye lashes, normal colour of hairs and with no hyperplasia of root of nose. Skin was normal in colour and no hypo pigmented patch was seen.

Appearances of milestones were in normal range. Systemic examination was within normal limits. Ophthalmic examination revealed nothing abnormal. $\mathrm{W}$ index was 1.77 . Her response to the sound did not raise any suspicion of defective hearing. 
Investigations revealed no biochemical abnormality. Radiologically no disturbance was noted in the musculoskeletal system. B E R A (brain stem evoked response audiography) showed normal results.

DISCUSSION: Waardenburg syndrome, was firstly reported by Jan van der Hoeve in 1916. In 1951 Dr. Petrus J Warrdenburg, defined the six characterstic features of this syndrome. In literature four types of waardenburg syndrome are described on the basis of clinical and genetic criteria. ${ }^{2}$ All types reflect marked variability.

Waardenburg syndrome type I (WS 1) is the most benign form of its four types. The cardinal features are dystopia canthorum (99\%), hypopigmentation of iris, hair and skin, congenital deafness, tubular nose and synophrys. When deafness is not present, these persons are basically normal.

Waardenburg syndrome type II (WS 2) is a heterogenous group without dystopia canthorum. Sensorineural hearing loss is found in $77 \%$ cases, while heterochromia iridum is found in $47 \%$ cases. Other clinical manifestations eg. White forelock, skin patches, hyperplasia of root of nose are more frequent in type I.

Type III (Klein-Waardenburg syndrome) is similar to type I, but it is associated with musculoskeletal abnormalities.

Type IV (Shah-Waardenburg syndrome) is associated with congenital aganglionic megacolon (hirschprung disease).

This syndrome is inherited as an autosomal dominant trait. The multiple types of this syndrome result from mutation occurring in different genes. In general WS 2 occurs sporadically. The familial cases of WS 2 have also been reported in literature. No specific treatment is available for this syndrome, though the specific manifestations are treated accordingly. For deafness, hearing aids and proper schooling may be needed. Cochlear implantation has been done successfully in such cases. ${ }^{3}$

This is always beneficial to diagnose and manage the patient with deafness as early as possible. As this auditory deficit may hamper the physical as well as the mental growth, which may ultimately augment the degree of mental retardation and adjustments. WS4 patients need attention to their diet and medications to keep their bowel moving. Prevention in the shape of genetic counseling is the answer. One sided complete heterochrochromia with normal nose and absence of canthal dystopia in this case fulfilled the diagnostic criteria to label her as a case of waardenburg syndrome type II and its occurrence was sporadic. Genetic counseling was done.

\section{REFERENCES:}

1. Cullen et al. Cochlear implants in Waardenburg syndrome. Laryngoscope 2006 Jul; 116 (7): $1273-5$.

2. Dourmishev L A Waardenburg syndrome; Accessed January 10, 2007 Available from: http://www.e-medicine.

3. Flores-Sarnat. Waardenburg syndrome: clinical summary; Accessed January 10, 2007.Available from: http://www.medilink.com/cip.asp. 


\section{CASE REPORT}

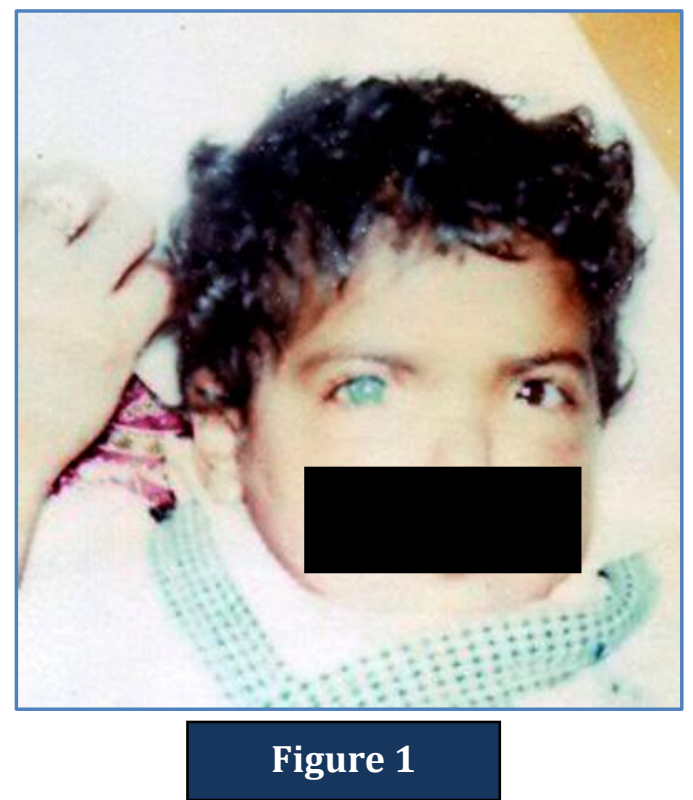

\section{AUTHORS:}

1. Santosh Kumar Singh

2. Sunil Kumar Gupta

3. Anand Agarwal

\section{PARTICULARS OF CONTRIBUTORS:}

1. Assistant Professor, Department of Dermatology, BRD Medical College, Gorakhpur.

2. Associate Professor, Department of Dermatology, HIMS, Safeabad, Barabanki.

3. Professor, Department of Paediatrics, HIMS, Safedabad, Barabanki.

\section{NAME ADDRESS EMAIL ID OF THE} CORRESPONDING AUTHOR:

Dr. Santosh Kumar Singh, Assistant Professor,

Department of Dermatology,

BRD Medical College,

Gorakhpur.

Email: drsantoshsingh15@gmail.com

Date of Submission: 27/09/2014.

Date of Peer Review: 28/09/2014.

Date of Acceptance: 18/10/2014.

Date of Publishing: 23/10/2014. 